\title{
Lapurdum
}

Euskal ikerketen aldizkaria | Revue d'études basques |

Revista de estudios vascos | Basque studies review

18 | 2014

Numéro XVIII

\section{Hiztunaren fonema inbentarioa eta elebitasun goiztiarra : euskara gehi frantsesa vs. euskara gehi gaztelania}

Miren Lourdes Oñederra, Oroitz Jauregi et Irantzu Epelde

\section{OpenEdition}

Journals

Édition électronique

URL : http://journals.openedition.org/lapurdum/2504

DOI : 10.4000/lapurdum.2504

ISSN : 1965-0655

Éditeur

IKER

Édition imprimée

Date de publication : 1 octobre 2014

Pagination : 75-95

ISBN : 978-2-86781-409-X

ISSN : $1273-3830$

Référence électronique

Miren Lourdes Oñederra, Oroitz Jauregi eta Irantzu Epelde, « Hiztunaren fonema inbentarioa eta elebitasun goiztiarra : euskara gehi frantsesa vs. euskara gehi gaztelania », Lapurdum [Linean],

18| 2014, Sarean emana----an 25 mai 2016, kontsultatu 01 mai 2019. URL : http:// journals.openedition.org/lapurdum/2504; DOI : 10.4000/lapurdum.2504 


\title{
Hiztunaren fonema inbentarioa eta elebitasun goiztiarra: euskara gehi frantsesa vs. euskara gehi gaztelania
}

\author{
Miren Lourdes OÑEDERRA \\ Euskal Herriko Unibertsitatea \\ Oroitz JAUREGI \\ Euskal Herriko Unibertsitatea \\ Irantzu EPELDE \\ IKER (UMR-5478)
}

\section{Laburpena}

Artikuluaren helburua da elebitasun goiztiarrak fonema inbentarioaren jabekuntzan eta gauzatzean izan dezakeen eragina aztertzea Euskal Herriko euskara-frantsesdun eta euskara-gaztelaniadun heldu elebidunen artean. Hots arrotzak bereganatzeko estrategia desberdinak erabiltzen ditu hiztun elebidunak, bere ama hizkuntzaren edo lehen hizkuntzaren fonemen arabera, eta jabekuntza adinak berebiziko pisua du jabekuntza prozesuan. Artikuluan gertakari hauek ditugu aztergai, Ipar Euskal Herrian gaur egungo euskara-frantsesdun elebidunekin egindako kasu azterketa zenbaiten bitartez.

\section{Abstract}

The purpose of the present study is to investigate the relations between early bilingualism and phoneme inventory among Basque-French and Basque-Spanish bilingual adults living in the Basque Country. The paper provides an overview of the complex issues that phonologists face when investigating the nativization of loanwords and, more generally, the ways in which unfamiliar sounds and sound sequences are adapted to converge with the native language's sound pattern. The general feeling is that loanword nativization provides a direct window for observing how acoustic cues are categorized in terms of the distinctive features relevant to the L1 phonological system as well as for studying L1 phonological processes in action and thus to the true synchronic phonology of Ll. The paper analyses these phenomena with a case study of Basque-French bilingual speech.

Gako hitzak: fonema inbentarioa, euskara-frantsesa, euskara-gaztelania, elebitasun goiztiarra.

Keywords: phoneme inventory, Basque-French, Basque-Spanish, early bilingualism. 


\section{Abiapuntu teorikoa}

Fonologia Naturalaren (h.a. FN) teorigile nagusienetakoa den Patricia Doneganek (1995: 62) honela azaltzen ditu tasun fonetikoak hizkuntz jabekuntzaren testuinguruan:

(...) through auditory (and proprioceptive) feedback, the child begins to establish motor-auditory-kinesthetic connections, connections between articulatory gestures or positions and their acoustic or auditory effects (...). These associations of particular gestures or kinds of gestures with particular acoustic effects can be identified with what phonologists call 'phonetic features'.

Lan horretan bertan adierazten du nola haurra, alderdi artikulatorio eta akustikoak mentalki lotzearekin tasunez jabetzeaz gainera, ohartuko den tasunak aldi bereko multzoetan gertatzen direla hots unitateak osatuz, eta tasun batzuk beste batzuk baino bateragarriago zaizkiola ebakeraren edo oharmenaren aldetik (edo alde bietatik). Ezagutza hori baliatuko du inguruko hizkuntzaren fonemak bereganatzeko. ${ }^{1}$

Fonema batzuek tasun fonetikoen bateragarritasun onenaren murriztapenei men egingo diete. Esate baterako, bokal ahokariak bokaltasuna sudurkaritasunarekin batera gertatzearen zailtasunak saihestearen emaitzatzat har daitezke (eta hala hartzen dira FNean). Oso grosso modo, bokal sudurkarien ebakeran sudurrerako bidea irekia izatearen zailtasun aerodinamikoei gehitzen zaizkie, oharmenaren aldetik, sudurkaritasunak dakarren bokal nolakotasunaren margultzea (alegia, hobekiago hautematen direla bokal ahokariak bokal sudurkariak baino).

Fonologia Naturalean murriztapen hauek ingurunegabeko bilakabide fonologikotzat hartzen dira. Hala, esan genezake bokal ahokariak bokalen sudurkaritasuna saihesten duen bilakabide baten emaitza direla:

$$
\begin{gathered}
\mathrm{V} \rightarrow \\
\Downarrow \\
\\
\mathrm{la} /
\end{gathered}
$$

Beren fonema inbentarioan bokal ahokariak bakarrik dituzten hizkuntzen fonologian bilakabide hau emankorra dela esango dugu. Halakoak dira euskara eta gaztelania.

1.- Artikulu honen gai nagusia fonema-unitateak dira, fonema bilkuretan sortzen diren gertakari fonologikoak bidenabar bakarrik agertuko dira, gai nagusiak ukitzen baditu.

Ondoko ikerketa proiektu hauen babesean egin da lan hau: AThEME (EC FP7/SSH-2013-1 613465), ACOBA (ANR-2010-BLAN-1911-01), MINECO Ekonomia eta Lehiakortasun Ministerioa (FFI2012-33190) eta EHU 13/19. 
Beste fonema batzuk, berriz, tasun fonetikoen bateragarritasun onenaren murriztapenak gaindituz edo atzenduz bereganatuko ditu haurrak. Halakoak dira, besteak beste, bokal sudurkariak. Fonema mota hori bereganatzeko, haurrak gauza izan beharko du tasun fonetikoak modu zailagoan eta oharmen-ondorio txarragoekin lotzeko elkarrekin. Bestela esan, jakin beharko du, bokal sudurkaria sortzeko, bokalari dagozkion ahots bidearen jarrera eta mugimendu anatomikoekin batera sabai biguna jaisten eta sudurrerako bidea irekitzen biriketatik datorren aireari. Horretarako, noski, oharmenaren aldetik gauza izan behar izan du bokalen sudurkaritasuna bere horretan, bokalaren osagaitzat (eta ez ingurunearen eragintzat) hartzeko. Esan genezake bokalen ahokaritasuna bermatzen duen bilakabideari uko egin zaiola, ondoko irudian grafikoki erakutsi nahi izan dugun bezala.

$$
\begin{gathered}
\forall \rightarrow[\text {-nasal] } \\
\Downarrow \\
/ \tilde{a} /
\end{gathered}
$$

Bilakabideen ukatzeak, alderdi fonetikotik (hotsaren ekoizpenari edo oharmenari dagokionean, alegia) onuragarri ez direnez, ahoskeraz jabetzean haurrak bakar-bakarrik atzenduko ditu ikasten ari den hizkuntzak nahitaezko dituen hots-bereizkuntzak bermatuko dizkion bilakabideak: "In learning to pronounce a language, the speaker learns to overcome only those constraints his language requires him to" (Donegan 1995: 64).

Hain zuzen ere, bilakabide fonologiko batek tasun fonetikoen konbinaketa onena bermatzen duen aldetik, murriztu egiten du gerta daitezkeen hotsen multzoa, litekeen aurkakotasun batean erlatiboki onena den kidea bakarrik gordeaz. Esaterako, esku artean darabiltzagunen artean, bokalak ahokaritasunarekin lotzen dituen bilakabideak bokal sudurkariak bereizteko ahalmena kentzen dio hiztunari. Bilakabide hori emankor den hizkuntza bateko hiztunek ezin izango dituzte bokal sudurkariak berez hauteman, beraz ezta gogoan hartu ere, eta, ondorioz, ez dute izango bokal sudurkariak berariaz ahoskatzerik. ${ }^{2}$ Hitz teknikoagoetan laburturik, ez da bokal sudurkaririk egongo beren fonema inbentarioan, FNak azaltzen duen moduan, fonemak baitira hiztunaren ustez hots posibleak, gerta daitezkeen hotsak: "The phoneme is a unit of perception, mental representation, and intention" (Donegan \& Stampe 2009: 16).

2.- Bai agian ingurune egokian, euskaraz eta gaztelaniaz gertatu ohi den bezala bokala kontsonante sudurkari baten aurretik ahoskatzen denean, batez ere sudurkari hori silaba berean badago: ondo [õndo], horren baitan [orẽmbajtãn]. 
Ondoko taulak euskarazko hots inbentarioa islatzen du, hau da, euskal fonemak.

\begin{tabular}{|c|c|c|c|c|c|c|c|c|c|c|c|c|}
\hline & $\begin{array}{l}\text { Ezpain. } \\
-\mathrm{A}+\mathrm{A}\end{array}$ & $\begin{array}{l}\text { Ezpainho. } \\
-\mathrm{A} \quad+\mathrm{A}\end{array}$ & $\begin{array}{l}\text { Hortzart } \\
-\mathrm{A}+\mathrm{A}\end{array}$ & $\begin{array}{l}\text { Horzk. } \\
-\mathrm{A}+\mathrm{A}\end{array}$ & $\begin{array}{l}\text { Hob } \\
-\mathrm{A}\end{array}$ & $\begin{array}{l}\mathrm{p.} \\
+\mathrm{A}\end{array}$ & $\begin{array}{l}\text { Hob. Lep. } \\
-\mathrm{A}+\mathrm{A}\end{array}$ & $\begin{array}{l}\text { Sabaiaur. } \\
-\mathrm{A}+\mathrm{A}\end{array}$ & $\begin{array}{l}\text { Sabaik. } \\
-\mathrm{A}+\mathrm{A}\end{array}$ & $\begin{array}{l}\text { Belar. } \\
-\mathrm{A}+\mathrm{A}\end{array}$ & $\begin{array}{l}\text { Fari. } \\
-\mathrm{A}+\mathrm{A}\end{array}$ & $\begin{array}{l}\text { Ubul. } \\
-\mathrm{A}+\mathrm{A}\end{array}$ \\
\hline Herskaria & $\mathrm{p} \quad \mathrm{b}$ & & & $\mathrm{d}$ & & & & & c & k $\quad \mathrm{g}$ & & \\
\hline Hersk.has. & $p h$ & & & th & & & & & & $k h$ & & \\
\hline Sudurkaria & $\mathrm{m}$ & & & & & n & & & $\mathrm{j}$ & & & \\
\hline Dard.anitza & & & & & & $r$ & & & & & & $R$ \\
\hline Ttak-a & & & & & & r & & & & & & \\
\hline Igurzkaria & & f & $\theta$ & & s & & $\mathrm{s}_{\mathrm{a}}$ & J & & $\mathrm{x}$ & $\hbar$ & \\
\hline Afrikatua & & & & & ts & & ts & ts & & & & \\
\hline \multicolumn{13}{|l|}{ Hurbilk. } \\
\hline Albokaria & & & & & & 1 & & & i & & & \\
\hline Irristaria & & & & & & & & & $\mathrm{j}$ & $\mathrm{w}$ & & \\
\hline
\end{tabular}

\section{Taula. Euskararen hots inbentarioa.}

Taula honek islatzen dituen hotsetan bereizkuntza bat egiten da tipografiaren bidez: etzanean agertzeak adierazten du hotsak ez direla orokorrak euskal eremu osoan, aldiz etzanean ez dauden hotsak orokorragotzat har daitezke, nahiz eta horietako zenbait ere ez izan orokorrak, adibidez erabilera eremua galtzen doan /ș/ igurzkari hobikari lepokaria. Bokalei dagokienez, /i e a o u/ bokal orokorrei, zubererazko /y/ bokala ere gehitu behar zaie.

\section{Elebitasunari buruzko hipotesia}

Hizkuntza bi aski goiz (honetaz gehiago hurrengo paragrafoan) bereganatzen baditu haurrak, espero genuke hizkuntza biek behar dituzten fonema guztietarako tasun konbinaketez jabetuko dela. Haurrak hizkuntza biek erabiltzen dituzten konbinaketa onenak gordeko ditu, eta ez-hain-onak egiteko traba egiten duten murrizketak (bilakabideak) atzenduko ditu hala behar badu. Hartara, bi hizkuntza horietako bakoitzak eskatzen dituen fonema guztiak hiztunaren fonema inbentarioan egongo dira. Bestela esan, edozein hizkuntzak atzentzen duen tasun fonetiko konbinaketa, atzentzeko ahalmena bereganatuko duela hiztunak eta, horrela, gai izango dela tasun konbinaketa berri horrek dakarren unitatea hautemateko eta baita ahoskatzeko ere.

Bi hizkuntza «aski goiz» bereganatu behar direla esan dugu. Hizkuntzaz jabetzeko adinaren epe eta mugez asko esan da, asko idatzi da (ikus beza irakurleak critical age terminoaren inguruan pilaturiko bibliografia zabala). Ez gara gu hemen eztabaida sakon eta konplexu horretan sartuko. Haatik, denbora eragile garrantzitsua dela dakigunez (Flege et al. 1999, Wong 1991, MacSwan \& Pray 2005), eta hemen proposatzen dugun hipotesia betetzeko baldintza ezinbestekotzat jotzen dugunez, gutxieneko mugarri bat kokatzeko saioa egingo dugu. Onenean, gainera, hemen aurkezten den hipotesia egia bada, berau izan liteke jabekuntza adina zehazteko bide bat. 
Ahoskeraren aldetik hizkuntza «aski goiz» ikastea litzateke hizkuntzaren sistema fonologikoaz arazorik gabe jabetzeko aski gazte izatea, gorago azaldutakoaren haritik, hizkuntzak behar dituen tasun konbinaketa guztien jabe egiteko. Egia da zirkular samarra gerta daitekeela, baina, kontuan hartzen badugu hizkuntzak, jabetze goiztiarrean, fonetika zailduaz unitate fonemikoen inbentarioa aberasten duela, lanean hasteko erabaki genezake hiztun bati fonema mota bat falta zaionean, fonema mota horri legokiokeen tasun konbinaketaren beharra beranduegi iritsi zaiola hiztunari (honezkero oharmen edo ekoizpen gaitasuna lehen hizkuntzaren sistemaren inguruan zurrunduta daukanean). ${ }^{3}$ Zalantzarik gabe, jabekuntza aski goiztiarra sendoen bermatzen duena da haurrak hizkuntza biak hasiera-hasieratik entzutea. Hasiera-hasieratik nerabezarorako tarte horretan hasiera bera den egokiena edo geroxeago hasita ere jabekuntza fonologikoa ziurtatzen den, eztabaida eta ikerketa asko behar duen gaia da oraindik. Emaitza enpirikoen arabera, badirudi jaiotza baino lehenago ere badela gauza umea sistema fonologiko berriak bereganatzeko, eta, gainera, desberdintasunak daudela gaitasun horren epeetan banakoen artean (Flege 1999, Sebastian-Gallés et al. 1999, 2006).

Hiztunaren elebitasun goiztiarraz gainera, noski, zenbait baldintza soziologiko ere aintzat hartu behar dira hiztunen datuen analisirako. Besteak beste, hizkuntza biak aski erabiltzen dituen familia edo talde eta gizarte batean bizi behar du haurrak. ${ }^{4}$

Datuen analisirako garrantzitsu den beste gogoeta bat ere bada, hemen labur azalduko duguna: hizkuntza bietako batean bakarrik gertatzen diren fonemak maileguetan eta forma berezietan besterik ez gertatzea beste hizkuntzan (adibidez, lapurtar baten hizketan bokal sudurkariak frantsesetikako maileguetan bakarrik azaltzea). Dena dela, hiztunek hautematen dituzten neurrian, esan daiteke beren fonema inbentarioan daudela, hiztunaren baliabide linguistiko direla (gogora goragoko fonema definizioa).

\section{Datuek diotena: fonemen gehitzea}

Esan genezake, oro har, hiztun gaztelaniadun edo frantsesdun elebakarraren antzera, euskal elebidun berantiarrek ez dituztela izaten euskaraz bakarrik diren fonemak. Hala nola, hiztun gaztelaniadunak ez ditu izango /c/ sabaikaria, /ts/ afrikatua, /// igurzkari sabaiaurrekoa edo, $/ K /$ albokaria. Halaber, gaztelaniatik abiatuta euskara beranduegi ikasten duenak ere ez ditu izango edo, gutxienez, bereziki kostatuko zaio unitate horiek behar bezala bereiztea. Hiztun horien ahoskeran ohikoak izaten dira ondoko ordezkatzeak:

$$
\begin{aligned}
& \text { kitto [kitfo] ([kico]-ren ordez) } \\
& \text { Xabi [tfaßi] ([Jaßi]-ren ordez) }
\end{aligned}
$$

3.- Hemen egiten ari garen sinplifikazioa aitortu behar da: badira, bestela ere eta berez bezala, hizkuntzak galtzen dituen fonema motak. Hemen oso oinarrizko eskema marraztu nahi izan dugu bigarren hizkuntzaren ikaste berantiarra goiztiarretik bereizteko.

4.- Agian horrek — baldintza hori ez guztiz betetzeak - elkartzen ditu, adibidez, /z/ren erabilerarik ezean ikastolarik gabeko gazteak Parisera joandako zaharrekin. 


\author{
ertzaina [ertfana] ([ertșaja]-ren ordez) \\ antzoki [ant foki] ([antşoki]-ren ordez) \\ llabur [jaßur] ([Kaßur]-en ordez)
}

Bestalde, elebidun goiztiarrak, alegia, bi hizkuntzez batera jabetu direnak edo bigarrena beren sistema fonologikoa zurrundu aurretik ikasi dutenak, euskarazko aurkakotasun paradigmatiko guztiak menperatzeaz gain, beste hizkuntzaren (gaztelaniaren edo frantsesaren) fonemak baliatzeko gauza dira. Beren ahoskeran goian aipatutako ordezkatze horiek ez gertatzeak erakusten du euskararen fonemak badituztela, eta beste hizkuntza horretako maileguen ahoskerak erakusten du nola frantsesetikako fonemak gertatzen diren euskarafrantsesdun elebidunengan. Ikus ondoko adibideetan bokal sudurkariak, aitzineko bokal biribilduak, dardarkari ubularra eta igurzkari ezpainhorzkari ahostuna5:

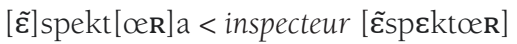

$$
\begin{aligned}
& \text { [ã]trepren [œ]r (ona) < (bon) entrepreneur [ãtrəpRənœe] } \\
& \text { [v]itesa }<\text { vitesse [vites] }
\end{aligned}
$$

Gauzak ez ziren hala, noski, belaunaldi zaharragoetan, euskara zutenengan lehen hizkuntza eta frantsesa bigarren. Frantsesezko maileguen ondoko ahoskerak salatzen du hiztun horiei frantsesa iritsi zitzaienerako beren sistema fonologikoa euskarak baldintzatzen zuela erabat, euskarazko fonemek ordezkatzen baitituzte frantses sistema fonologikoari legozkiokeenak:

$$
\begin{gathered}
\text { fat }[\mathrm{u}] \mathrm{rra}<\text { facteur }[\text { faktœe }] \\
\text { [b]itesa }<\text { vitesse }[\text { vites] }
\end{gathered}
$$

Berriz ere maileguek nabarmentzen digute nola gaztelania-euskaradun elebidun goiztiarragan gaztelaniaren $/ \theta$ / fonema igurzkari horzkaria sartu den:

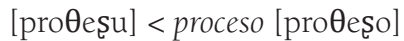

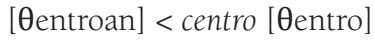

$$
\begin{aligned}
& \text { [konsisten } \theta \mathrm{ja} \text { ] < consistencia [konsisten } \theta \mathrm{ja} \text { ] } \\
& \text { [kons } \theta j e n t e]<\text { consciente [kons } \theta \text { jente] }
\end{aligned}
$$

Mailegu izan gabe, bi hizkuntzetan berdin esaten diren izen berezietan ere ikusten

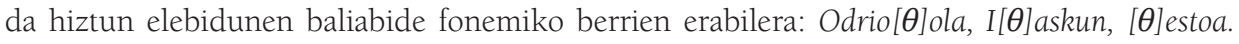
Hori ez zen hala belaunaldi zaharragoetan, eta ezta oraindik ere euskararen fonologia osorik bereganatu ondoren gaztelaniazkoa zatika bakarrik hartu dutenengan. Duela hogeita hamar bat urteko grabazioan Astigarragako hiztun baten Odrio[s]ola edo [krus], gaztelaniazko cruz

5.- Ondokoetan ez dira maileguak erabat transkribatu euskal ahoskeran ez baititugu zehazki aztertu aipagai ditugun unitateak baizik. 


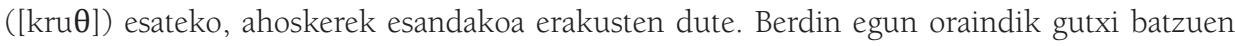
gaztelanian entzun daitezkeen parece [pareșe] edo funciona [funtsjona].

Oro har ematen du elebidun goiztiarrek ez dituztela fonema inbentario bereziak, baizik eta bereganatu dituzten hizkuntza bien unitateak biltzen dituztela, eta unitate horiek erabiltzen dituztela hizketa bahetzeko oharmenaren bidez. Gero bere baitan dituzten unitate beroriek erabili ahal izango dituzte hitzak kanporatzean ere. Frantsesez edo gaztelaniaz eta ez euskaraz gertatzen ziren hots-unitateak, noski, ez dira gertatuko euskarazko hitz berezkoetan. Ez legoke horretarako arrazoirik. Jakinaren gainean edo bestela idatzia oinarri hartzen duenak bakarrik pentsa lezake jatorrizko euskal hitzetan gerta litezkeela [ $\theta$ ] igurzkari hortzarteko edo bokal sudurkariak. Euskal hitz zaharren aurkezpen fonemikoan ez daude halako tasun konbinaketak. Haatik, halako fonemak dituenak, bereganatu duen beste hizkuntzak ikasarazi dizkiolako, erabili ahal izango ditu eta erabiliko ditu, kanpotikako hitz batek halako unitateak dakarzkionean. Horregatik, fonema berri horien existentzia maileguetan, akronimoetan eta kidekoetan bakarrik hauteman daiteke.

\section{Fonemak galtzea}

Atal honetan bi fonema galtze aipatuko dira: bata, Hegoaldeko elebidunengan gertatzen ari dena, $/ K /$ fonemaren galera ( $\$ 4.1)$; bestea, berriz, Iparraldeko euskaran abian dagoena: hasperenaren galera (\$4.2).

\section{1. / $/$ / fonemaren galera}

Gauza ezaguna da gaztelania-euskara elebidunen artean gero eta gehiago direla $/ \mathrm{K} /$ fonema ez daukatenak beren fonema inbentarioan. Hiztun zaharragoek fonema horren bidez gauzatzen dituzten ahoskerak, albokaritasunik gabe gertatzen dira gazteagoengan: esate baterako, ilun zaharragoen [iKun] fonema galdu duten gazteagoengan [ijun] edo [iłun] bihurtu da. Teknikoki esango genuke desalbokaritze bilakabide baten aurrean gaudela.

Albokariaren galtze hori erlatiboki lehenago gertatu denez gaztelaniaz, eta gaztelaniatik abiatzen direnek euskara ikasteko desalbokaritzea ezartzen dutenez euskararen ahoskeran, automatikoki egotzi izan zaio gaztelaniaren eraginari euskarak fonema albokaria galtzea. Elebitasunaren testuinguruan gertatu bide den nolabaiteko eragina ukatu gabe ${ }^{6}$, esan behar da fonemaren galtze honek areago dirudiela geografikoki hedatuz doan aldaketa bat, gaztelaniaren eragin zuzena baino. Oro har, ematen du adina dela eragile nagusiena eta elebitasun mailak ez duela lotura zuzenik fonemaren sendotasunarekin. Hiztun zaharragoek, euskaradun izan edo ez, albokaria dute eta gazteagoengan urrituz doa.

6.- Ikus Oñederra 2012. Garbi dago euskara bigarren hizkuntza dutenen eredua oso hedatua dagoela gizarteko gune garrantzitsuetan (besteak beste, irakaskuntzan). 


\subsection{Hasperenaren galera}

Aipatu nahi dugun beste fonema galera Iparraldeko euskarazko /h/ hasperenarena da. Fonema hori ere desagertuz doa, azken aldi honetako ikerketek erakusten dutenez (cf. \$5.1). Iparraldeko hizkeretan (kostaldean izan ezik), bost ingurune fonetikotan gordetzen da hasperena, baina ez hiztun guztietan, eta ez maiztasun berarekin. Kasu honetan ere, galera adinarekin doa eskuz esku. Hizkuntza aldaketetan adina izaten da eragile nagusietako bat (Chambers 2002), eta hain zuzen aldaketa gauzatzen ari den seinale izan ohi da berrikuntza adinean beherago eta indar handiagoz agertzea (Labov 1994, Trudgill 1974). Gure lekukoen artean ere, gazteago eta nabarmenago atzematen da, oro har, hasperenaren galera.

Badirudi hasperena, garai batean euskalki guztiek batera zutena, aski berandu arte gorde zela mendebalean (Araba, Errioxa, Bizkaia), nahiz hamaseigarren menderako desagertua zen. Mitxelenak dio (2011 [1961]: 169) galera Goi Nafarroan hasiko zela ziurrenik, Aragoiko erromantzearen eraginez. XI. menderako ez omen zegoen hasperenaren arrastorik alderdi horretan.

\section{Hiru saio, hiru bilakaera}

Gaur egungo euskal hizkerek aztergai oparoa eskaintzen dute fonema unitateetan gerta daitezkeen bilakaerak ikusteko, egoera elebidun desberdinak baititu euskara hitz egiten deneko eremuan. Bosgarren atal honetan eremu jakin bati begiratuko diogu: Iparraldean 2011-2014 bitartean egindako inkesten emaitzak bakarrik hartuko ditugu kontuan. Oro har, $\$ 1$ atalean teorikoki azaldutakoa eremu honetan nola gauzatzen den ikustea da helburua, horretarako hiru saioren emaitzak erakutsiz. Hiru fenomeno motari begiratuko diogu: fonema baten galtzea (hasperena vs hasperenik eza; \$5.1); euskarak ez duen eta frantsesak baduen ezaugarri baten ahoskera (bokal ahokariak vs bokal sudurkariak; 85.2); eta, azkenik, euskal hots baten ordez frantsesetikako beste hots baten ordezkatzea (dardarkari hobikaria vs dardarkari ubularra; §5.3).

\subsection{Fonema galtzea: hasperenaren ekoizpena, gaur}

Goragoko 4.2. azpiatalean aurreratu bezala, hasperenaren galeraz bakarrik ariko gara fonema galtzeei eskainitako azpiatal honetan. Galera honi «aspirazio galera» edo «deaspirazio» ere esan izan zaio literaturan. Badira euskarak aspirazioa sistema osoan izan zuela baieztatzen duten lanak (cf. Mitxelena 2011 [1961], Hualde 1991); hau da, hizkuntzaren historiaren garai batean euskal eremu guztian eta euskalki guztietan zabaldua zela aspirazioa unitate fonemiko gisa. Denborak aurrera egin ahala, erabilpen eremua galduz joan zen, eta gaur egun, batez ere, zubereraz gordetzen da (neurri apalagoan behe-nafarreraz, eta oraindik apalagoan lapurteraz). Galera honen berri badakar, adibidez, Vinsonek, bere garairako hasperena «en voie de disparition» zegoela aipatuz (1914: 59; ik. Daranatz 1931 ere). Hartatik mende bat igaro denean, interesekoa iruditu zaigu berrikuntza hau pixka bat polikiago aztertzea, ikusteko bilakaera honek zein neurritaraino egin duen aurrera (cf. Jauregi \& Epelde 2013). Hasperena alderdi askotatik azter daitekeen gertakaria da, eta 2013ko lan horretan deaspirazioa izan genuen gai nagusia. Fonema jakin honen bitartez, gaur egun gertatzen ari den berrikuntza bat eta hartzen duen gutxi gorabeherako hedadura azaltzen saiatu ginen, horretarako berriki jasotako datuak erabiliz. 
Metodologiari dagokionez, sei hitz edo sintagma labur itzultzeko eskatu zitzaien NoRANTZ $^{7}$ egitasmoko 59 lekukoei, betiere hasperenaren hitz hasierako eta bokalarteko posizioak bereiziz. Egitasmo horretan hiru adin multzo hartu ziren kontuan: 70 urtetik gorakoak (guztira 15 lekuko), 40-60 urte artekoak (12 lekuko) eta 35 urtetik beherakoak (32 lekuko). Sei galdera horietako bakoitza 59 hiztuni egin zitzaionez, 354 erantzun lortu ziren guztira, eta horiek dira 2013ko lanaren oinarria. Xedea izan genuen akustikoki aztertzea bat-bateko erantzun horietatik lekukoek zenbat —eta zein — ebaki zituzten hasperenez, eta zenbat —eta zein - hasperenik gabe. Aztergaiari dagokionez, hasperena hitz hasieran eta bokalartean agertu/ez agertu izan da kontuan hartu genuena, kanpo utziz kontsonante herskari hasperendunak eta kontsonante ozenen ondoren ekoizten diren hasperenak.

\subsubsection{Hitz hasierako hasperena}

Hauek dira hitz hastapeneko hasperenak neurtzeko erabili ziren galderak (NoRANTz galdetegian F129-F131 kodeen arteko galderak):

1. Une pierre $>[h]$ arri bat

2. Un enfant $>$ [h]aur bat

3. Là-bas $>[h] a n$

Emaitzei begiratzen badiegu, ikusiko dugu gazteen artean herenak besterik ez zuela hitz hasierako hasperena ebaki (zehazki, \%31k). Beraz, \%69 izan ziren hitz hasieran batere hasperenik ahoskatu ez zuten lekukoak. Kontraste argia ikusi genuen hemen berriemaile zaharrenen ahoskerekin alderatzen badugu: 70 urtetik gorakoetan, \%74k hasperenez ebaki zituen proposatutako item horiek, eta $\% 26 \mathrm{k}$ batere gabe. Ondoko grafikoan irudikatu dira emaitzak:

7.- Proiektuaren izenburu ofiziala da: 'Projet Norantz: Contact de langues et variation linguistique: création d'un observatoire des nouveaux parlers basques' eta finantzatu zuten erakundeak honako hauek: Akitaniako Eskualde Kontseilua, Pirinio Atlantikoetako Kontseilu Orokorra eta Euskararen Erakunde Publikoa. Iraupena: 2008ko irailaren letik 2011ko abuztuaren 31ra. Datu gehiago aurki dezake irakurleak Oyharçabal, Salaberria \& Epelde 2011 eta 2012 lanetan. Web interfazea helbide honetan aurki daiteke: www. norantz.org 


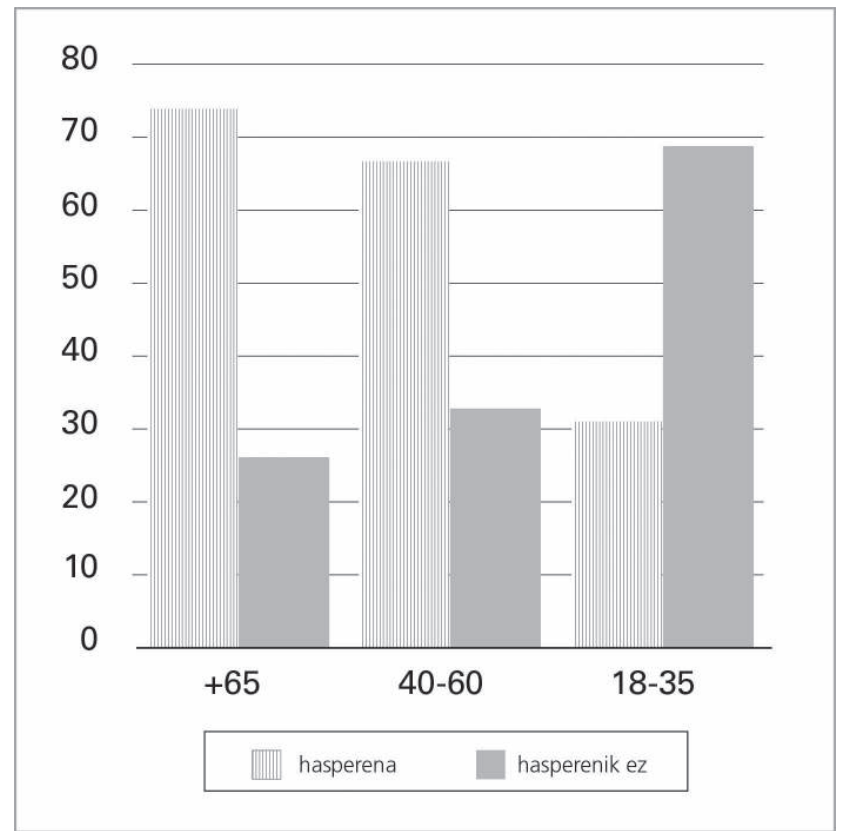

1. irudia. Hasperena hitz hasieran, NoRANTz egitasmoko datuen arabera.

\subsubsection{Bokalarteko hasperena}

Hauek dira bokalarteko hasperenak neurtzeko erabili ziren galderak (NoRANTz galdetegian F135-F137 kodeen arteko galderak):

4. Lit $>$ o[h]ea

5. Table $>$ ma[h]ai(n)a

6. Vouloir $>$ na[h]ia / na[h]ikeria

Bokalartean, oro har, hitz hasieran baino maiztasun txikiagoarekin gertatzen da hasperena, datuen arabera. 70 urtetik gorakoak dira, berriz ere, bokalarteko hasperenak maizenik ahoskatzen dituztenak: \%53k bai eta \%47k ez. Goragoko 4.2. puntuan aurreratu bezala, kasu honetan ere galera adinarekin doa eskuz esku. Izan ere, gazteen artean asko jaisten da hasperendunen kopurua: \%2lek ebakitzen du eta \%79k batere ez (cf. 2. irudia jarraian): 


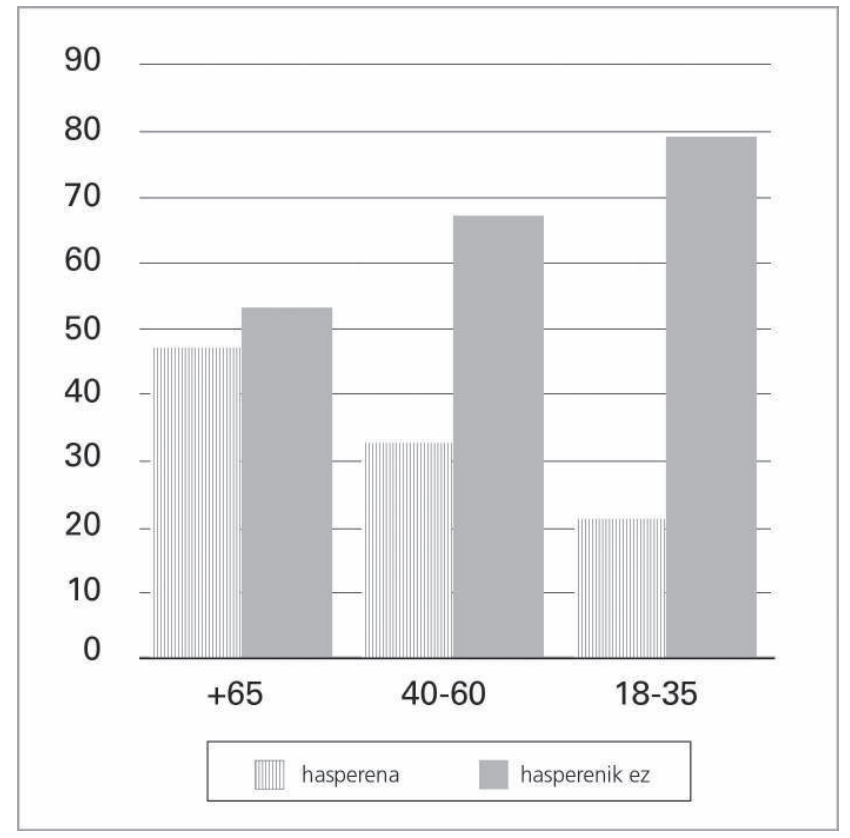

2. irudia. Hasperena bokalartean, Norantz egitasmoko datuen arabera.

Oro har, bilakabide ingurunegabeen ${ }^{8}$ zergatiez gogoeta egiteko parada eskaini digute lan honen emaitzek. Alderdi fonetiko-fonologikotik begiratuta, esan daiteke artikulatorioki aspirazioa ekoizteak ez ekoizteak baino zailtasun handiagoa dakarrela, eta oharmenaren aldetik ez dela horren hots unitate ziurra sortzen (betiere, adibidez, kontsonante herskari batekin alderatzen badugu; Hurch 1988). Ondorioz, esan daiteke deaspirazioa aspirazioa baino bilakabide naturalagotzat har daitekeela. Beraz, hizkuntzaren egiturari begiratuta, /h/rik gabeko sistema bat naturalagotzat har daiteke /h/dun sistema bat baino. Argudio fonetiko-fonologikoek, hortaz, ez lukete egingo aspirazioa galtzearen aurka.

Bestalde, gehitu behar dugu ondoko hizkuntza nagusiaren eragina ere hor dagoela: gaurko frantsesak ez du hasperenik, ezta erdialdeko euskarak eta euskara estandarrak ere. Hasperena galtzearen aldeko indarrak hainbat izan daitezkeelakoan gaude (2013: 259):

1. Fonetikoki dena alde du deaspirazioak: artikulatorioki, akustikoki eta oharmenaren aldetik hasperena ez gertatzeak abantaila gehiago du gertatzeak baino.

2. Hizkuntz jabekuntzan egon daitezkeen aldagaiak erabakigarriak izan daitezke; hau da, hizkuntza jabekuntza noiz-nola gertatu den (etxean, eskolan, eskolako eredu elebidunean,

8.- Hots, aldameneko beste hotsen batek eragin ez duen bilakabideen zergatiez. 
D ereduan...).

3. Frantsesaren eragina.

4. Euskara estandarraren eta erdialdeko euskalkiaren eragina.

\subsection{Bokal sudurkariak: euskarak ez dituen fonemak (eta frantsesak badituenak) nola gauzatzen diren ikusteko adibide bat}

Euskaraz, oro har, bost bokal unitate fonemiko daudela esan izan dute euskalariek (Mitxelena 2011 [1961], Hualde 1991, Oñederra 2004), eta bokal sudurkaririk ez dagoela. Gaur egungo bokal sudurkariak maileguen testuinguruan izan genituen langai orain ez aspaldi (Epelde \& Jauregi 2011a, b). Urte hauetan egindako alor lanean belarriz hautemandakoa akustikoki neurtu nahi izan genuen, gaur egungo hiztun lapurtarren ahoskera kontuan hartuz. Sudurkaritasunaren bitartez, gertatzen ari den aldaketa baten berri ematen saiatu ginen: frantsesak bokal ahokariez gain bokal sudurkariak ere badituenez, ikusi nahi izan genuen frantsesezko hitzak mailegatzerakoan euskaraz bokal sudurkariak gordetzen diren, edo, berezkoa zaion sistemaren arabera, euskarak bokal horiek ahokari bihurtzen ote dituen. 2011b lan hartan lapurterazko datuetara mugatzea erabaki genuen, eta Lapurdi barruan Senpereko berriemaileak hautatu genituen inkesta lanak egiteko. Gure lekuko haiek bokal sudurkariak zenbateraino ebakitzen zituzten ikusi nahi izan genuen horrela, datu akustikoak erabiliz. Labur esateko, lekuko senpertar hauek euskaraz ari direnean eta euskarazko diskurtsoan frantsesezko maileguak erabiltzen dituztenean, ea bokal sudurkariak ekoizten dituzten edo ez. Horrek berez bezala ekarriko luke lapurterazko euskara-frantsesa elebidun goiztiarrak [bokalak $\rightarrow$ ahokari] egiten dituen bilakabidea gainditua duela baieztatzea, eta horren arabera hiztuna gai litzateke bi bokal motak berariaz ekoizteko, fonemikoki ebakitzeko, nahiz gero zein-noiz egin aukeratzeko gaitasun osoa izan. Ez da ahaztu behar hiztun guztiak elebidunak direla gaur egun.

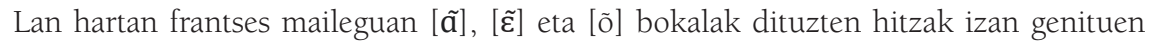
aztergai, euskarazko ordainetan bi unitate (bokala eta kontsonante sudurkaria) edo bakarra (bokal sudurkari edo sudurkaritua) egiten zen ikusi nahian.

Azterketa akustikoa egiteko, lau hiztun hautatu ziren, laurak Senperekoak: hiru adinekoak ( 80,86 eta 89 urte) eta gazte bat ( 26 urte). ${ }^{9}$ Galdeketak egiteko, berriz, hitz zerrenda bana aurkeztu genien hiztunei frantsesezko hamarna hitzekin, eta horiek euskaraz emateko eskatu. Euskaraz egunero erabiltzeko modukoak ziren hitz guztiak. Ondoren, euskarazko 10 hitzeko zerrenda bana aurkeztu genien, eta horiek ozenki esateko eskatu. ${ }^{10}$ Euskarazko hitz

9.- Grabaketak hiztunen etxeetan egin ziren, Sony MD Walkman eta Sony ECM-717 mikrofono aparailuekin. Grabatutako seinalea ordenagailura M-Audio-ren bidez pasatu eta gero, neurketak Praat programarekin egin genituen. Azterketa akustikoa egiteko hots uhina eta espektrograma erabili ziren.

10.- Esperimentuaren diseinuaren aldetik, eta bi hitz motak lortzeko metodo bera erabiltzearren, komeni zen beharbada euskarazko hitzak ahoskatzeko garaian ere frantsesezko ordainak ematea, gero hiztunek euskarazkoak eman zitzaten. Hartara, bokal eta kontsonante sudurkari bilkura idatziz ikustea saihestuko genukeen. Guk bestela jokatzea hobetsi genuen, berriemaileei gauzak errazteagatik. 
guztietan (C)VN. ${ }^{11}$ bilkura lehenengo silaban dago, ez dago bat ere hitz amaieran duenik. Frantsesetiko maileguetan ere agertzen da bokal sudurkaria lehen silaban, adibidez ambulance eta invitation hitzetan; amaieran dutenek askotan beste kontsonante bat ere badute jarraian, adibidez science, lampe eta pompe hitzek. Hau da, sudurkaria ez dago erabateko amaieran. Kontrol hitzak ere aztertu genituen, eta horiek lortzeko hizketa librea erabili zen.

Emaitzei begira, euskarazko hogei itemei dagokienez, ia kasu guztietan bi unitate gertatzen zirela erakutsi zuten espektrogramek: kanbiatu, kanta eta ganbara moduko hitzetan bokalak eta kontsonante sudurkariak bakoitzak bere denbora hartzen duela bereiz zitekeen espektrograman. Hala ere, bi unitate hain garbi antzematen ez zireneko kasuak ere aurkitu genituen.

Frantsesezko itemei dagokienez, laburki esateko, 20 kasuetatik 13tan (\%65etan) bokal sudurkariak ekoitzi zituzten hiztunek. Beste zenbait adibide (20tik 7), bi unitate eginez [bokala (neurri handiagoan edo txikiagoan sudurkaritua) + kontsonante sudurkaria] ebaki zituzten, uhin espektrografikoen arabera.

Garbi ikusten da bokal sudurkarien jabe direla, neurri handiagoan edo txikiagoan, lan hartan aztertutako hiztunak. Honekin batera esan behar da zahar/gazte banaketan desberdintasunak ikus zitezkeela: lekuko gazteena eta adintsuena kontuan hartuz, lekuko gazteak bokal sudurkariz ebaki zituen bi mailegu zahar (serg[ã]ta 'sanjentua' eta k[õ]zientziaik 'kontzientziarik') erabat euskararen fonologiaren arabera eman zituen adinekoak: sarienta mailegu egokituarekin, alde batetik, eta kontzientziarik guztiz eta aspaldi euskaratutakoarekin, bestetik.

Esan behar da adinaren araberako aldakortasuna oso kontuan hartu beharrekoa dela, hiztun bakoitzaren barne aldakortasunarekin batera. Adibidez, [ã]nvelopa ahoskatu zuten gure lekukoek, baina beste hiztun batzuen ahotik entzun izan dugu euskararen arauen arabera egokituta mailegu hori: enbelopa, $[v]>[b]$ bilakatuz eta are emelopa, askotan sudurkariak asimilatu egiten duelako ondoko herskaria $[\mathrm{mb}]$ eta $[\mathrm{nd}]$ multzoetan.

Maileguaren antzinatasuna erabakigarria dela ikusten da egokitze graduari dagokionez. Oro har, mailegu zaharretan euskararen fonologia arauen arabera egokitu dira hotsak, linja (fr. linge) eta xinple (fr. simple) hitzetan gertatu den bezala (ez dira sudurkaritzen eta unitate bakarrean biltzen). Maileguaren antzinatasuna zenbateraino den erabakigarri oso garbi ikusten da NORANTZ egitasmoko datuetan, eta baita hiztun zahar/gazte kontrastea ere, mailegu zaharrak eta berriak erabiltzerakoan. Lekuko zaharrenak, 86 urtekoak, behin bakarrik ebaki

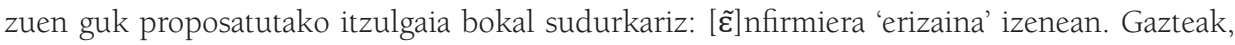
pentsatzekoa zenez, umetatik ikasia zuen euskarazko ordaina (18 urte arte ikastolan ibilia da), eta, espero genuen bezala, erizaina itzuli zuen. Gauza bera gertatu zen anpula/bonbilla, trantxa/ xerra eta ponpierak/suhiltzaileak pareekin, adibidez.

11.- Silaba bukaerako kontsonante sudurkaria adierazi nahi dugu N. honekin. 
5.3. Dardarkariak: euskal hots baten ordez frantsesezko beste hots baten ordezkatzea nola gauzatzen den ikusteko adibide bat

Euskaraz, oro har, dardarkarien sailean dardarkari hobikaria eta ttak hobikaria aipatu izan dira, hots unitate gisa, bokalartean soilik oposizioan daudenak. Hemen aipatuko dena abian dagoen aldaketa bat da, Iparraldeko hizkeretan gertatzen ari den ia erabateko ordezkatze bat: euskaraz ez dagoen baina frantsesez badagoen dardarkari ubularrak euskarazko dardarkari hobikaria ordezkatzea hiru euskalkietan (L), (BN) eta (Zub). ${ }^{12}$ Ordezkapen fonetikoa da kasu honetan: artikulazio gunea aldatzen da, eta dardarkaria hobikari izatetik ubular izatera pasatzen da.

Norantz datu-baseak bilduma oparoa eskaintzen digu gaur egungo hiztunek fonema hau nola ebakitzen duten ikusteko: guztira 11.671 erantzunetan agertzen dira honelako dardarkariak, hainbat ingurunetan. Dardarkariari eskainitako galdera berezitu batzuk ere badira galdetegian. Adibidez, frantsesezko hitz hasierako dardarkariari gaur egun protesirik ezartzen zaion edo ez ikusteko, bost galdera sartu ziren datu-basean:

F48 - Ils mettent des radars partout.

F49 - Le radiateur est froid.

F50 - Le robinet est cassé.

F51- Il y a des rubans autour du paquet.

F52 - J'ai dû écrire un nouveau rapport.

Beste 24 galdera ere eskaini zitzaizkien dardarkariei, gainerako inguruneetan nola ebakitzen diren ikusteko, bai frantsesezko maileguetan eta bai mailegu ez direnetan. Galdetegia, osorik hartuta (568 galdera ditu morfosintaxiari dagozkionak eta 178 fonologiari dagozkionak; guztira, 746 galdera) datu-iturri oparoa da euskarazko hitzetan fonema honen ahoskeraren gorabeherak neurtzeko, galdetegian zehar beste hainbat galderatan ere agertzen direlako dardarkariak, hainbat ingurunetan. Har dezagun, adibidez, galdetegiko lehendabiziko galdera, izenaren morfologiari dagokiona (ergatiboa):

\section{Al - L'homme a apporté du poisson.}

Galdera horri emandako erantzun guztietan aurki ditzakegu ek(h)arri eta arraina/arraña hitzak, informatzaile guztiek horien bitartez itzuli zutelako perpaus hori (Gizonak ekarri $d u$ arrain (a), aldaera fonetikoak gorabehera). Datu-basea, gaur egungo hotsen ebakeraz eskaintzen duen informazio fidagarriagatik, ezin utzizko lanabesa begitantzen zaigu, eta ez dugu zalantza handirik izan erantzun horietan oinarritzeko. Hona hemen emaitzak, dardarkariari dagokionez lekuko bakoitzaren ebakera erakusten dutenak (hobikaria vs ubularra):

12.- Badira bilakabide gehiago dardarkariei dagokienez eremu honetan, baina oraingoan ordezkatze hau bakarrik aipatuko dugu. 


\begin{tabular}{|l|c|}
\hline ESHEN & {$[\mathrm{r}]$} \\
\hline JABI & {$[\mathrm{r}]$} \\
\hline MADON & {$[\mathrm{R}]$} \\
\hline LOUSEN & {$[\mathrm{r}]$} \\
\hline GERBAR & {$[\mathrm{r}]$} \\
\hline XALEZ & {$[\mathrm{r}]$} \\
\hline ANIZ & {$[\mathrm{R}]$} \\
\hline MAIHE & {$[\mathrm{r}]$} \\
\hline BELU & {$[\mathrm{R}]$} \\
\hline REES & {$[\mathrm{r}]$} \\
\hline PIEPA & {$[\mathrm{r}]$} \\
\hline PIEGE & {$[\mathrm{R}]$} \\
\hline JOBAN & {$[\mathrm{r}]$} \\
\hline ADBAR & {$[\mathrm{r}]$} \\
\hline XLEAHA & {$[\mathrm{R}]$} \\
\hline
\end{tabular}

2. Taula. Adinekoen emaitzak NORANTZ egitasmoan:

$\%$ 53,3k [r] ebaki dute eta \% 46,6k, [R].

\begin{tabular}{|l|c|}
\hline JEDON & {$[\mathrm{R}]$} \\
\hline RAZI & {$[\mathrm{R}]$} \\
\hline YOSAN & {$[\mathrm{r}]$} \\
\hline PIMUS & {$[\mathrm{r}]$} \\
\hline GRAAR & {$[\mathrm{R}]$} \\
\hline XALAI & {$[\mathrm{R}]$} \\
\hline KOBA & {$[\mathrm{R}]$} \\
\hline MOBA & {$[\mathrm{R}]$} \\
\hline BERLA & {$[\mathrm{R}]$} \\
\hline MIMU & {$[\mathrm{r}]$} \\
\hline KADO & {$[\mathrm{R}]$} \\
\hline EHI & {$[\mathrm{R}]$} \\
\hline
\end{tabular}

3. Taula. 40-60 urte bitartekoen emaitzak NORANTZ egitasmoan:

$\%$ 25ek [r] ebaki dute eta \% 75ek, [R]. 


\begin{tabular}{|c|c|}
\hline MAAL & [R] \\
\hline SEAI & {$[\mathrm{R}]$} \\
\hline XAAN & {$[\mathrm{R}]$} \\
\hline XABAI & {$[\mathrm{R}]$} \\
\hline LAUSA & {$[\mathrm{R}]$} \\
\hline ANHAZ & [R] \\
\hline IOSEN & {$[\mathrm{R}]$} \\
\hline BEDO & {$[\mathrm{R}]$} \\
\hline MAIAZ & [R] \\
\hline NAZI & [R] \\
\hline AKAN & [R] \\
\hline EHEN & {$[\mathrm{r}]$} \\
\hline PABA & [R] \\
\hline JOAI & {$[\mathrm{R}]$} \\
\hline PANZI & [R] \\
\hline JOSA & [R] \\
\hline LUIDO & [R] \\
\hline MAIE & {$[\mathrm{R}]$} \\
\hline NAMAU & {$[\mathrm{r}]$} \\
\hline IBA & {$[\mathrm{R}]$} \\
\hline KABA & {$[\mathrm{R}]$} \\
\hline PEOLO & {$[\mathrm{R}]$} \\
\hline JOAINH & {$[\mathrm{r}]$} \\
\hline GORBA & {$[\mathrm{R}]$} \\
\hline $\mathrm{ABE}$ & {$[\mathrm{R}]$} \\
\hline AIBA & {$[\mathrm{R}]$} \\
\hline XILA & {$[\mathrm{R}]$} \\
\hline ALAZI & [R] \\
\hline MIMI & {$[\mathrm{R}]$} \\
\hline $\mathrm{KAU}$ & {$[\mathrm{r}]$} \\
\hline IBAI & {$[\mathrm{R}]$} \\
\hline MAILA & [R] \\
\hline
\end{tabular}

4. Taula. Gazteen emaitzak NORANTZ egitasmoan:

$\% 12,5 \mathrm{ek}$ [r] ebaki dute eta \% 87,5ek, [R] 
Tauletan ikus daitekeenez, emaitzek garbi erakusten dute dardarkari hobikariak kategoria fonemiko nahiko ahula duela. Frantsesezko hots batek euskarazkoa ordezkatzean nagusi den hizkuntzaren eragina faktore erabakigarria da, datuen arabera. Zenbaitetan euskara estandarraren eragina ere ikus daiteke, batez ere euskaraz eskolatutako hiztunetan, horiek dardarkari hobikariaren alde ere egiten baitute, bereziki eskolako eremuan ikasitako hitzetan. Oro har, dardarkariarekin gertatzen denak ere artikuluaren lehen parte teorikoan azaldutakoa berresten du. Saio hauetan parte hartu zuten hiztun guztiak elebidunak dira, haietako asko elebidun goiztiarrak, eta, beraz, haur garaian ikasitako hizkuntzetako hots unitateak ekoizteko gai dira, baita oharmenaren aldetik haiek 'entzuteko' gai ere. Horrez gain, eragile soziolinguistikoen garrantzia ere ezin alde batera utzizkoa da fonema sailaren gaur egungo ekoizpenari dagokionez, datuek erakusten duten moduan. Lehen hurbilpen hauek, dena dela, polikiago aztertzea mereziko luke ondorengo lanetan.

\section{Ondorio gisa}

Artikuluan saiatu gara erakusten bi hizkuntzaren jabekuntzagatik hiztun elebidunen sistema fonologikoan nolako ondorioak gerta daitezkeen. Gure kasuan, batez ere adina hartu dugu kontuan hizkuntzaz kanpoko faktore moduan, eta abian diren zenbait aldaketarekin hiru saio egin dira. 5. atalean, Lapurdi, Nafarroa Beherea eta Zuberoako euskaradun eta frantsesdun hiztunei egindako galdeketen bidez, teoria fonologikorako interesgarri izan daitezkeen gertakari batzuk erakutsi ditugu, hiztun elebidun horiengan gaur egun indarrean dauden zenbait bilakabide fonologiko neurtuz eta aztertuz.

Oraindik lan asko badago ere egiteko, uste dugu esan daitekeela euskararen datuek erakusten dutela elebitasun goiztiarrak ez diola berez hiztunari fonemarik 'kentzen'. Ikasten dituen hizkuntza bien (edo gehiagoren) fonemak biltzen dituen neurrian, elebitasun goiztiarraren emaitza bat izango litzateke elebakarrak dituen fonema kopurua baino gehiago izatea elebidunak, hiztuna gai delako hizkuntza bateko zein besteko unitate fonemikoak erabiltzeko, eta ondorioz baita unitate horien oharmenaz jabetzeko ere. Bokalen sudurkaritasuna da egoera hau erakusteko erabili dugun adibideetako bat, eta, aurreko lanetan azaldu bezala (2011a, b), maileguen ahoskera da horren adibide agerikoena.

Artikuluan zehar ikusi dugu bilakabide fonologiko batek fonema galera ere ekar dezakeela zenbaitetan. Albokariaren kasua aipatu dugu hau ikusteko (§4.1), baina batez ere hasperenaren galera aztertu da polikiago (\$5.1). Bi hots horien galera areago aztertu beharko litzateke, hizkuntzaren berezko garapenaren testuinguruan. Zalantzarik ez dago hizkuntza baten sendotasun linguistiko eta sozialak zeresan handia duela hiztunen gaitasunaren izaeran, gaitasun fonologikoa barne. Horrek zein neurritan eragin dezakeen fonema mota markatuenak (halakoak dira bai albokaria eta bai hasperena) ahultzean, ongi aztertzea merezi lukeen gaia da:

Researchers have noted a tendency for contraction in phonological systems leading to the loss of oppositions. Campbell and Muntzel (1987: 187) hypothesize that the marked number of a phonological opposition will be more likely to disappear. In El Salvador, for instance, Pipil has lost contrastive vowel length, a distinction not found 
in the dominant language, Spanish, while in Tuxtla Chico Mam the merger of /q/ and $/ \mathrm{k} /$ in favour of $/ \mathrm{k} /$ has likewise eliminated the marked member of the opposition. However, these reductions are also consistent with Andersen's (1982: 92) prediction that subordinate language distinctions not matched in the dominant language will be vulnerable to elimination (Romaine 2010: 330-31).

Egoera elebidunen eraginez sortutako berrikuntzetan hirugarrena fonema ordezkatzea aipatu dugu (\$5.3): adibidez, Iparraldean dardarkari hobikaria ahoskatu beharrean dardarkari ubularra ahoskatzea. Azken batean, fonema baten ahoskune aldaketa litzateke: dardara hobietan egin beharrean ubulan egitea. Ikusi dugu dardarkari ubularra erabat zabaldu dela hiztun gazteenen artean, eta aldaketa berri-berria dela: adinekoen taldean erdiek ubularra eta erdiek hobikaria ahoskatu zuten NoranTz egitasmoko lekukoen artean.

Kontaktuan dauden hizkuntzen artean gertatutako hots aldaketen berri emateko, ikusi dugu, alde batetik, hizkuntzaren beraren hautuak daudela, alegia, inolako hizkuntzarekin ukipenean egon gabe ere, edo hasieran ukipen egoeran egonagatik, hizkuntzaren beraren barruan indarra hartuaz joan direnak, hasperenaren kasuan bezala (\$5.1).

Aldiz, ukipen egoeran izanik, eta hizkuntza bien egoera soziologikoa hain desorekatua den eremuan, hizkuntza nagusiaren eta egoera ahulenean dagoenaren ezaugarriak kontuan hartu behar dira. Alderdi hau, hizkuntzan hotsei dagozkien aldaketen azterketan saihestu ezinezkoa da, eta sakontasun handiagoz aztertzea mereziko lukeena. Gure kasuan, frantsesaren eta euskararen egoera soziolinguistikoak hizkuntza bien ezaugarri fonologikoetan duen eragina zuzenean aztertzea lekarke, zalantzarik gabe aurrerantzean egin beharreko lana litzatekeena. Besteren artean, ikusi beharko litzateke hizkuntza erkidego desberdinetan, eta baita norbanako bakoitzarengan ere.

Ondoren aipatuko diren eragileak frantsesaren eraginarekin batera lantzea merezi luke, eragin hori neurtzen lagunduko luketelako elebitasun goiztiarrean. Eragileetako bat litzateke irakaskuntza formalaren eragina, eta baita erdialdeko euskararekiko zein euskara estandarrarekiko lotura edo lotura falta ere. Eragile hauek, adibidez, hasperena ez egitearen alde egingo lukete, deaspirazioaren alde (Jauregi \& Epelde 2013).

Honen haritik, Iparraldeko dialekto desberdinetan hiztun mota desberdinetan ikasketa prozesu desberdinak aztertu beharko lirateke. Hain zuzen ere, bereizi beharko genituzke L1 euskara eta L2 frantsesa duten hiztunak aldi berean euskaraz eta frantsesaz jabetu diren hiztunengandik, esanguratsuak izan baitaitezke desberdintasun honetatik atera ditzakegun ondorioak. Honekin batera, hiztun zaharrenekin lan egitea ezinbestekoa litzateke.

Amaitzeko, merezi du azpimarratzea hemen aipatu diren bilakabide bakoitzak bere azalpena eskatuko lukeela, ezin dela bilakabide guztientzat azalmolde fonologiko zein soziololinguistiko bakarra eskaini. Aldiz, uste dugu kasu guztiak batera aurkezteak hiztun elebidunen sistema fonologikoetan gertatzen dena modu argigarrian erakusten duela. Oraindik lan asko egin behar bada ere, ausartuko ginateke esatera euskararen datuek erakusten dutela elebitasun 
goiztiarrak ez diola hiztunari fonemarik kentzen ${ }^{13}$. Ikasten dituen hizkuntza bien fonemak biltzen dituen neurrian, bere sistema fonologikoa ez da elebakar batena izango litzatekeena dudarik gabe. Maileguen ahoskera da horren erakusle agerikoena.

\section{Bibliografia}

Chambers, J. 2002. Patterns of Variation including Change. The Handbook of Language Variation and Change. Oxford: Blackwell, 349-372.

Daranatz, J.B. 1931. Correspondance du Capitaine Duvoisin. Revista internacional de los estudios $\operatorname{vascos} 22,310-337$.

Donegan, P. 1995. The innateness of phonemic perception. Proceedings of the 24th Western Conference on Linguistics (Volume 7). V. Samiian \& J. Schaeffer (arg.), Fresno, CA: Dept. of Linguistics, California State University, 59-69.

Donegan, P. \& Stampe, D. 2009. Hypotheses on Natural Phonology. Poznan Studies in Contemporary Linguistics 45/1, 1-31.

Epelde, I. 2011. Lapurdiko itsasegiko euskararen ahoskera: Donibane Lohizune. Koldo Mitxelena Katedraren II. Biltzarra - II Congreso de la Cátedra Luis Michelena - 2nd Conference of the Luis Michelena Chair. J. A. Lakarra, J. Gorrochategui, \& B. Urgell (arg.). VitoriaGasteiz, UPV/EHU, 307-322.

Epelde, I. \& Jauregi, O. 2011a. Bokal sudurkariak tentatzen. Pirinioetako hizkuntzak: lehena eta oraina. A. Sagarna, J. Lakarra \& P. Salaberri (arg.). Iker 26, Euskaltzaindia, 973-989.

Epelde, I. \& Jauregi, O. 2011b. Bokal sudurkariak gaurko lapurteran. Lapurdum 15, 29-42.

Flege, J.E. 1999. Age of learning and second language speech. Second language acquisition and the critical period hypothesis, 101-131.

Flege, J.E., Yeni-Komshian, G.H., \& Liu, S. 1999. Age constraints on second language acquisition. Journal of Memory and Language 41, 78-104.

Hualde, J.I. 1991. Basque phonology. London: Routledge.

13.- Ikus Oñederra 2009. 
Hurch, B. 1988. Über Aspiration. Tubingen: Gunter Narr Verlag.

Igartua, I. 2001. La aspiración en vasco: ensayo tipológico y diacrónico. Anuario del Seminario de Filología Vasca 'Julio de Urquijo' 35/1, 185-231.

Labov, W. 1994. Principles of Linguistic Change: Internal Factors. Oxford: Blackwell.

Lafon, R. 1948. Remarques sur l'aspiration en basque. Mélanges offerts à M. le prof. Henri Gavel. Toulouse, 55-61.

Jauregi, O. \& Epelde, I. 2013. Hasperenaren galera Iparraldeko euskaran. Koldo Mitxelena Katedraren III. Biltzarra - III Congreso de la Cátedra Luis Michelena - 3rd Conference of the Luis Michelena Chair. R. Gómez, J. Gorrochategui, J. A. Lakarra \& C. Mounole, (arg.), VitoriaGasteiz, UPV/EHU, 245-262.

MacSwan, J. \& Pray, L. 2005. Learning English bilingually: Age of onset of exposure and rate of acquisition of English among children in a bilingual education program. Bilingual Research Journal 29 (3), 687-712.

Mitxelena, K. 2011 [1961]. Fonética histórica vasca. Obras completas de Luis Michelena. J. Lakarra \& I. Ruiz Arzalluz, (arg.), ASJUren gehigarriak LIX, 6. liburukia.

Oñederra, M.L. 2004. Fonetika fonologia hitzez hitz. Bilbo: Euskal Herriko Unibertsitatea.

Oñederra, M.L. 2009. Early bilingualism as a source of morphonological rules for the adaptation of loanwords: Spanish loanwords in Basque. In Loan Phonology. A. Calabrese \& W. L. Wetzels (arg.), John Benjamins, 193-210.

Oñederra, M.L. 2012. Sobre la deslateralización de las palatales o 'yeísmo'. In El castellano en el País Vasco. B. Camus \& S. Gómez, (arg.), ASJUren gehigarriak LXX, 139-154.

Oyharçabal, B., Salaberria, J. \& I. Epelde. 2011. Norantz datu-basea: aurkezpena eta aditz komunztadurako datuak. In Euskal dialektologia: lehena eta oraina. I. Epelde (arg.), ASJUren gehigarriak LXIX, Euskal Herriko Unibertsitatea, 1-36.

Oyharçabal, B., Salaberria, J. \& I. Epelde. 2012. La base de données Norantz: vers un observatoire des parlers basques d'Aquitaine. Lapurdum 16, 27-67.

Romaine, S. 2010. Contact and Language Death. In The Handbook of Language Contact. R. Hickey (arg.), Wiley-Blackwell, 320-339.

Sebastian-Gallés, N., Rodríguez-Fornells, A., de Diego-Balaguer, R., \& Díaz, B. 2006. Firstand second-language phonological representations in the mental lexicon. Journal of Cognitive Neuroscience 18 (8), 1277-1291. 
Sebastián-Gallés, N., \& Soto-Faraco, S. 1999. Online processing of native and non-native phonemic contrasts in early bilinguals. Cognition 72 (2), 111-123.

Trudgill, P. 1974. Linguistic change and diffusion: description and explanation in sociolinguistic dialect geography. Language in Society 3, 215-246.

Vinson, J. 1914. La phonétique basque et le néo-latin. Revista internacional de los estudios vascos 8, 361-367.

Wong Fillmore, L. 1991. When learning a second language means losing the first. Early Childhood Research Quarterly 6, 323-346. 